\title{
运动康复训练对慢性心力衰竭患者 休液因子的影响及疗效观察
}

\author{
丁 懿 ${ }^{1}$, 郭琛琛 ${ }^{2}$, 孙敬龙 ${ }^{1}$, 王万宏 ${ }^{3}$, 侯王君 ${ }^{3}$, 庄 贺 $3^{*}$ \\ 1 山东中医药大学第二附属医院, 山东 济南 250001 ; \\ 2 山东第一医科大学附属颈肩腰腿痛医院, 山东 济南 250062; \\ 3 山东中医药大学, 山东 济南 250355
}

收稿日期: 2020-10-26; 接受日期 : 2020-12-26

基金项目: 中国民族医学会科研课题 (2019KYXM-Z1 100-38); 山东省中医药科技发展计划项目课题(2019-0238);

山东省健康养老研究中心项目 (JKYLO4); 山东中医药大学中医传统功法康复青年科研创新团队项目

DOI : 10.3724/SP.J.1329.2021.01004

开放科学 (资源服务)标识码 (OSID) :

摘要 目的: 探讨运动康复训绕对慢性心力衰竭(CHF) 的疗效以及对超氧化物歧化酶(SOD)、同型半胱氨 酸 (Hcy)、血管紧张素 II (Ang II)、乳酸 (LA) 和脑利钠肽 (BNP) 形成的影响, 为 CHF 的临床治疗提供循证医 学证据。方法: 依据随机数字表法将 76 例 CHF 患者分为对照组和联合组, 每组 38 例。对照组进行常规药物 治疗; 联合组在对照组治疗基础上进行运动康复训练。观察 2 组治疗前后总有效率及各项体液因子指标的 变化情况。给果: 联合组患者总有效率为 $89.47 \%$, 对照组 $73.68 \%$, 联合组总有效率优于对照组 $(P<0.05)$; 治 疗前 2 组患者的心功能等级分布情况比较, 差异无统计学意义 $(P>0.05)$, 治疗后联合组心功能等级分布情 况优于对照组, 差异有统计学意义 $(P<0.05)$; 治疗前 2 组患者血清 Ang II 、SOD、Hcy、LA 及 BNP 水平比较, 差异均无统计学意义 $(P>0.05)$; 治疗后 2 组患者血清Ang II H H y 、 LA 及 BNP 水平显著降低, SOD 水平明 显增高, 差异均有统计学意义 $(P<0.05)$; 治疗结束后, 联合组患者血清 Ang II、Hcy、LA 及 BNP 水平降低优 于对照组, 差异均有统计学意义 $(P<0.05)$, 联合组患者的 SOD 水平增高也优于对照组, 差异有统计学意义 $(P<0.05)$ 。结论: 在常规药物治疗基础上联合运动康复训练较单纯药物治疗, 能更有效调节相关体液因子, 在一定程度上影响 CHF 患者的血管内皮功能, 减少 LA 含量, 增强心功能, 疗效肯定, 值得临床推广应用。

关键词慢性心力衰竭; 运动康复疗法; 体液因子; 血管内皮功能; 心功能

慢性心力衰竭 (chronic heart failure, CHF, 简称 心衰)主要是继发于冠心病、高血压心脏病、风湿性 心瓣膜病。由冠心病和高血压诱发的比例呈逐年升 高趋势 ${ }^{[1]}$,其主要临床表现为活动后出现气促、易于 疲劳和体液潴留等症状,最终会严重影响患者的工 作能力和生活质量, 因此对于 $\mathrm{CHF}$ 的治疗越来越受 到重视。既往研究认为 ${ }^{[2]}, \mathrm{CHF}$ 的康复治疗可通过运 动康复训练以减轻患者生理和心理上的影响,降低 猝死风险,改善心脏临床症状,甚至逆转心室重构, 但是尚无运动康复训练对相关体液因子的影响。基
于此, 本研究探讨运动康复训练对 CHF 患者可能的 疗效作用机制, 为该治疗方案的进一步推广应用提 供新的循证医学证据支持。

\section{1 临床资料}

\section{1 病例选择标准}

1.1.1 诊断标准 符合《2016 年 ESC 急慢性心力衰 竭诊断与治疗指南》中关于 CHF 的诊断标准 ${ }^{[3]}$ 。

1.1.2 纳人标准 (1) 经检查确诊为冠心病患者, 年 龄 $45 \sim 70$ 岁; (2) 均有心衰的临床表现, 且.多普勒彩

引用格式: 丁懿, 郭堔堔, 孙敬龙, 等. 运动康复训练对慢性心力衰竭患者体液因子的影响及疗效观察 $[\mathrm{J}]$. 康复学报, 2021,31(1):24-29.

DING Y, GUO C C, SUN J L, et al. Effect of exercise rehabilitation training on humoral factors in patients with chronie heart failure and its effect observation [J]. Rehabilitation Medicine,2021,31(1):24-29.

DOI: $10.3724 /$ SP.J.1329.2021.01004 
色超声显示左心室射血分数(LVEF)低于 $50 \%$; (3) 患 者心衰病情稳定, 常规药物治疗能够缓解; (4) 患者 非文盲, 能够理解研究组人员给予的任何指令, 服从 安排; (5) 知情同意,签署知情同意书。

1.1.3 排除标准 (1) 伴严重的肝、肾、脑、肺等功能 异常,有严重主动脉狭窄、严重心律失常、不稳定性 心绞痛等; (2)患者曾接受过心肺复苏或电除颤治 疗, 或安装有心脏起搏器; (3) 精神疾病未实施有 效控制; (4) 恶性肺瘤; (5) 合并慢性阻塞性肺疾病 (COPD)、未控制高血压、血糖者; (6) 其他疾病或情 况影响本次研究。

1.1.4中止和剔除标准 (1) 受试者的依从性差, 不 能严格执行本治疗方案者; (2) 在治疗过程中, 突发 其他严重疾病 (脑、肺栓塞、心肌梗死等) 不宜继续 治疗者。

\section{2 一般资料}

收集 2018 年 6 月一-2019 年 12 月在山东中医 药大学第二附属医院心内科住院的 76 例 CHF 患 者, 通过随机数字表法分为对照组和联合组, 每组 38 例。2 组一般资料比较, 差异无统计学意义 $(P>$ $0.05)$, 见表 1 。本课题研究方法经山东中医药大学 第二附属医院伦理委员会审批通过。

\section{2 方 法}

\section{1 治疗方法}

2.1.1 对照组 只进行常规治疗, 根据《心力衰竭
表 12 组一般资料比较

Table 1 Comparison of general data between two groups

\begin{tabular}{|c|c|c|c|c|c|c|c|}
\hline \multirow{2}{*}{ 组 别 } & & \multicolumn{2}{|c|}{ 性别 } & \multirow{2}{*}{ 年龄/( $\bar{x} \pm s$, 岁 $)$} & \multicolumn{3}{|c|}{ 心功能分级 } \\
\hline & & 男 & 女 & & II 级 & III 级 & IV 级 \\
\hline 对照组 & 38 & 23 & 15 & $54.20 \pm 7.50$ & 13 & 20 & 5 \\
\hline 联合组 & 38 & 21 & 17 & $53.80 \pm 7.40$ & 14 & 18 & 6 \\
\hline
\end{tabular}

合理用药指南》 ${ }^{[4]}$ 对患者病情合理进行强心、利尿、血 管扩张等对症治疗,药物选用地高辛、阿托伐他汀、 噻嗪类利尿药、美托洛尔、螺内酯等, 同时对患者的 合并症进行对症处理。提倡患者根据自身情况进行 适当活动, 无具体运动方式、运动强度、运动频次和 运动时间的要求。

2.1.2 联合组 在常规治疗的基础上进行运动康 复训练。考虑到该组患者进行运动康复训练存在一 定的风险性, 为了有效管控风险, 或者使风险最小 化, 需在正式治疗前根据危险分层标准 ( $\mathrm{AHA}$ ) 进行 危险分层 ${ }^{[3]}$ 。同时参照冠心病和充血性心力衰竭分 级运动方案, 制定科学、合理、高效的分级运动方 案 ${ }^{[5]}$ 。运动量和运动强度需要根据患者的实际情况 来确定, 由低开始逐渐增加。心功能 III 级、 IV 级患者 的康复运动需要谨慎对待, 必须进行心电监护 (ECG) 和责任护士陪伴, 责任护士需以定时的方式, 对患 者的血压、心率、心律变化予以实时监测。患者在出 现明显不适时, 立即终止运动, 可适当延长康复疗 程, 以确保运动康复训练的连续性, 训练疗程为 3 周。 分级运动方案见表 2 。

\section{表 2 分级运动方案}

\section{Table 2 Graded exercise program}

\begin{tabular}{|c|c|c|c|}
\hline 时间 & 运动内容 & 活动级别 & 心功能分级 \\
\hline 第 $1 \sim 2$ 天 & 待病情稳定后进行被动活动,每日 2 次 & I 级 & IV 级 \\
\hline 第 3 4 4 天 & 按规定在床上主动进行脚、踝、膝关节活动 & I 级 & IV 级 \\
\hline 第 $5 \sim 6$ 天 & 按规定在床上主动进行胸、肩、上肢关节活动 & I 级 & IV 级 \\
\hline 第 $7 \sim 8$ 天 & $\begin{array}{l}\text { 有家属或护士协助下下床坐沙发或直背椅, 每次 } 10 \sim 30 \mathrm{~min} \text {, 每日 } 1 \sim 2 \text { 次, } \\
\text { 次数逐渐增加 }\end{array}$ & I 级 & IV 级 \\
\hline 第 $9 \sim 10$ 天 & 根据规定进行肩、颈部、双上肢的医疗体操活动 & II 级 & III 级 \\
\hline 第 11 天 & 平地步行 $100 \sim 200 \mathrm{~m}$,每日 2 次 & III 级 & II 级 \\
\hline 第 12 天 & 平地步行 $500 \mathrm{~m}$ 或上、下楼 1 层, 每日 2 次 & III 级 & II 级 \\
\hline 第 $13 \sim 14$ 天 & 平地步行 $1000 \mathrm{~m}$ 或上、下楼 2 层, 每日 2 次 & IV 级 & II 级 \\
\hline 第 $15 \sim 16$ 天 & 坡路步行 $1000 \mathrm{~m}$ 或上、下楼 3 层, 每日 2 次 & IV 级 & II 级 \\
\hline 第 $17 \sim 21$ 天 & 平地走路 $2000 \mathrm{~m}$ 或上、下楼 4 层, 每日 2 次 & IV 级及以上 & I 级 \\
\hline
\end{tabular}

2 组患者均接受健康教育干预。健康教育包括 单一指导、集体教育、联合两种教育 3 种形式, 旨在 让患者对自身所患的病症有清晰的认识, 密切配合 康复治疗。

\section{2 观察指标}

患者接受治疗前后,各采集 $5 \mathrm{~mL}$ 外周静脉血， 离心获得上层清液,测定体液因子: 血管紧张素 II (angiotensin II , Ang II )、同型半胱氨酸 (homocys- 
teine, Hcy)、超氧化物歧化酶 (superoxide dismutase, SOD)、乳酸 (lactic acid, LA) 和脑利钠肽 (brain natriuretic peptide, $\mathrm{BNP}$ ) 水平。

\section{3 不良反应及安全性检查}

为防止意外, 要求患者谨遵医嘱按时进行治疗 前后的相关常规检查。治疗过程中, 密切监测治疗 相关不良反应发生情况并详细记录其发生时间、原 因及程度,评估这些不良反应可能对后续治疗的影 响并采取针对性处理措施。本研究所有患者治疗期 间均未出现明显药物相关的不良反应; 联合组有 2 例 III级心功能患者在步行训练中出现了轻微胸闷、心 悸等症状, ECG 显示窦性心律,血压 135/80 mm Hg (无高血压病史), 心率 88 次 $/ \mathrm{min}$, 较之于治疗前, 心电图并没有出现变化, 其运动训练暂停, 休息约 $15 \mathrm{~min}$ 后, 胸闷、心悸等症状逐渐由轻到无。

\section{4 统计学方法}

数据采用 SPSS 21.0 软件进行统计分析。计量 资料用 $(\bar{x} \pm s)$ 表示, 数据符合正态分布, 组内比较采 用配对 $t$ 检验, 组间比较采用两样本 $t$ 检验; 计数资 料采用 $\chi^{2}$ 检验; 等级资料用 Mann-Whitney $U$ 秩和 检验。 $P<0.05$ 为差异有统计学意义。

\section{3 结 果}

\section{1 疗效判定标准}

表 42 组治疗前后心功能等级分布情况

Table 4 Distribution of cardiac function grades before and after treatment between two groups

\begin{tabular}{|c|c|c|c|c|c|c|c|c|c|}
\hline \multirow{2}{*}{ 组 别 } & \multirow{2}{*}{$n$} & \multicolumn{4}{|c|}{ 治疗前 } & \multicolumn{4}{|c|}{ 治疗后 } \\
\hline & & I 级 & II 级 & III 级 & IV 级 & I 级 & II 级 & III 级 & IV 级 \\
\hline 对照组 & 38 & 0 & 13 & 20 & 5 & 0 & 16 & 19 & 3 \\
\hline 联合组 & 38 & 0 & 14 & 18 & 6 & 6 & 17 & 13 & 2 \\
\hline
\end{tabular}

3.2.32 组不同 NYHA 心功能分级患者血清 Ang II 、Hcy、SOD 水平变化情况 经两样本 $t$ 检验统计 分析, 治疗前 2 组的血清 Ang II 、Hey 以及 SOD 水 平比较差异无统计学意义 $(P>0.05)$; 经过治疗后, 采用配对 $t$ 检验, 较治疗前患者血清 Ang II Hey 水 平出现了显著降低, SOD 水平也明显增高, 差异有 统计学意义 $(P<0.05)$; 经两样本 $t$ 检验, 治疗后联 合组患者的血清 Ang II H cy 水平降低优于对照组, 差异有统计学意义 $(P<0.05)$, 联合组患者的 SOD 水平也优于对照组, 差异有统计学意义 $(P<0.05)$ 。 见表 5。

3.2.4 2 组不同 NYHA 心功能分级患者血清 LA、 BNP 水平变化情况 经两样本 $t$ 检验统计分析, 治疗 前 2 组的 $L A 、 B N P$ 水平比较, 差异无统计学意义 $(P>$
以治疗前后患者的 NYHA 心功能分级变化情 况为基础 ${ }^{[6]}$ 。(1) 显效: 心功能改善 $\geqslant 2$ 级或上升至 1 级; (2) 有效: 心功能改善低于 2 级, 但 $\geqslant 1$ 级; (3) 无 效: 心功能改善低于 1 级; (4) 恶化: 心功能恶化程 度 $\leqslant 1$ 级。

\section{2 治疗结果}

3.2.12 组临床疗效比较 经 $\chi^{2}$ 检验, 2 组治疗后 联合组总有效率优于对照组, 差异有统计学意义 $(P<0.05)$ 。见表 3 。

表 32 组临床疗效比较

Table 3 Comparison of clinical efficacy between two groups

\begin{tabular}{ccccccc}
\hline 组别 & $n$ & 显效 & 有效 & 无效 & 恶化 & 总有效率 $/ \%$ \\
\hline 对照组 & 38 & 1 & 27 & 9 & 1 & 73.68 \\
联合组 & 38 & 3 & 31 & 4 & 0 & $89.47^{1}$ \\
\hline
\end{tabular}

注: 与对照组比较, 1) $P<0.05$ 。

Note: Compared with the control group, 1) $P<0.05$.

3.2.2 2 组治疗前后心功能等级分布情况经 Mann-Whitney $U$ 秩和检验统计分析, 治疗前 2 组的 心功能等级分布情况差异无统计学意义 $(P>0.05)$; 治疗后联合组患者的心功能等级分布情况优于对 照组, 差异有统计学意义 $(P<0.05)$ 。见表 4。
$0.05)$; 治疗结束后, 采用配对 $t$ 检验, 2 组 LA、BNP 水平较治疗前降低, 差异有统计学意义 $(P<0.05)$; 经采用配对 $t$ 检验, 治疗结束后, 联合组患者较对照 组 LA、BNP 水平降低, 差异有统计学意义 $(P<0.05)$ 。 见表 6 。

\section{4 讨 论}

《中国心血管健康与疾病报告 2019 概要》》 ${ }^{[7]}$ 推 算我国心力衰竭患者 890 万人,心血管病死亡居城 乡居民总死亡原因的首位, 已成为我国重大的公共 卫生问题。目前针对心衰的治疗仍以药物为主, 但 不可忽视的是大部分患者依然受到运动耐量下降、 呼吸不利、心绞痛等症状的困扰, 日常生活质量受 到严重影响。欧洲的心脏疾病指南将运动训练为核 
表 52 组不同 NYHA 心功能分级患者血清 Ang II、Hcy、SOD 水平变化情况 $(\bar{x} \pm s)$

Table 5 Changes of serum Ang II, Hcy and SOD levels in patients with different NYHA cardiac function grades between two groups $(\bar{x} \pm s)$

\begin{tabular}{|c|c|c|c|c|c|c|c|c|}
\hline \multirow{2}{*}{ 缉 别 } & \multirow{2}{*}{ NYHA } & \multirow{2}{*}{$n$} & \multicolumn{2}{|c|}{ Ang II $/(\mathrm{ng} / \mathrm{L})$} & \multicolumn{2}{|c|}{$\mathrm{Hcy} /(\mu \mathrm{mol} / \mathrm{L})$} & \multicolumn{2}{|c|}{$\mathrm{SOD} /(\mathrm{U} / \mathrm{mL})$} \\
\hline & & & 治疗前 & 治疗后 & 治疗前 & 治疗后 & 治疗前 & 治疗后 \\
\hline \multirow{3}{*}{ 对照组 } & II 级 & 13 & $65.8 \pm 11.9$ & $35.1 \pm 5.3^{1)}$ & $20.3 \pm 3.1$ & $15.9 \pm 3.0^{1)}$ & $90.0 \pm 9.7$ & $98.4 \pm 12.2^{1)}$ \\
\hline & III级 & 20 & $104.6 \pm 14.7$ & $55.7 \pm 13.1^{1)}$ & $24.5 \pm 3.2$ & $19.8 \pm 2.9^{1)}$ & $78.5 \pm 9.4$ & $85.3 \pm 10.6^{1)}$ \\
\hline & IV 级 & 5 & $141.8 \pm 10.3$ & $105.8 \pm 8.8^{17}$ & $28.7 \pm 3.6$ & $24.7 \pm 3.2^{1)}$ & $66.5 \pm 10.3$ & $73.4 \pm 9.1^{1)}$ \\
\hline \multirow{3}{*}{ 联合组 } & II 级 & 14 & $66.7 \pm 12.6$ & $30.8 \pm 5.0^{1 / 2)}$ & $20.1 \pm 3.3$ & $11.4 \pm 2.8^{1 / 2)}$ & $89.4 \pm 10.9$ & $106.7 \pm 11.4^{122}$ \\
\hline & III 级 & 18 & $102.2 \pm 13.5$ & $48.4 \pm 10.5^{1 / 2)}$ & $24.2 \pm 2.9$ & $15.2 \pm 2.6^{122)}$ & $78.9 \pm 9.6$ & $90.5 \pm 12.5^{1 / 2)}$ \\
\hline & IV 级 & 6 & $142.4 \pm 8.9$ & $96.3 \pm 9.4^{1 / 2)}$ & $28.6 \pm 3.0$ & $20.7 \pm 3.1^{1 / 2)}$ & $67.2 \pm 9.4$ & $81.6 \pm 9.8^{1 / 2)}$ \\
\hline
\end{tabular}

注:与治疗前比较, 1) $P<0.05$; 与对照组比较, 2) $P<0.05$ 。

Note: Compared with that before treatment, 1) $P<0.05$; Compared with the control group, 2) $P<0.05$.

表 62 组不同 NYHA 心功能分级患者血清 LA、BNP 水平变化情况 $(\bar{x} \pm s)$

Table 6 Changes of serum LA and BNP levels in patients with different NYHA cardiac function grades between two groups $(\bar{x} \pm s)$

\begin{tabular}{|c|c|c|c|c|c|c|}
\hline \multirow{2}{*}{ 缉 别 } & \multirow{2}{*}{ NYHA } & \multirow{2}{*}{$n$} & \multicolumn{2}{|c|}{$\mathrm{LA} /(\mathrm{mmol} / \mathrm{L})$} & \multicolumn{2}{|c|}{$\mathrm{BNP} /(\mathrm{ng} / \mathrm{L})$} \\
\hline & & & 治疗前 & 治疗后 & 治疗前 & 治疗后 \\
\hline \multirow{3}{*}{ 对照组 } & II 级 & 13 & $5.7 \pm 1.0$ & $5.2 \pm 0.8^{17}$ & $536.1 \pm 203.4$ & $418.6 \pm 158.3^{1)}$ \\
\hline & III 级 & 20 & $6.6 \pm 0.9$ & $6.0 \pm 0.8^{17}$ & $940.8 \pm 456.1$ & $634.6 \pm 305.0^{1)}$ \\
\hline & $\mathrm{IV}$ 级 & 5 & $7.3 \pm 0.8$ & $6.6 \pm 1.0^{1)}$ & $1260.9 \pm 573.5$ & $808.3 \pm 349.2^{1)}$ \\
\hline \multirow{3}{*}{ 联合组 } & II 级 & 14 & $5.7 \pm 0.8$ & $4.8 \pm 0.7^{122)}$ & $532.4 \pm 198.4$ & $326.5 \pm 109.7^{2}$ \\
\hline & III级 & 18 & $6.7 \pm 0.5$ & $5.6 \pm 0.9^{1 / 2)}$ & $938.0 \pm 429.1$ & $412.8 \pm 232.4^{1 / 2)}$ \\
\hline & $\mathrm{I}$ 级 & 6 & $7.3 \pm 1.0$ & $6.2 \pm 0.9^{1 / 2)}$ & $1241.6 \pm 560.5$ & $589.6 \pm 306.7^{1 / 2)}$ \\
\hline
\end{tabular}

注: 与治疗前比较, 1) $P<0.05$; 与对照组比较, 2) $P<0.05$ 。

Note: Compared with that before treatment, 1) $P<0.05$; Compared with the control group, 2) $P<0.05$.

心的心脏康复列为 I 级强推荐 ${ }^{[8]}$ 。大量研究已表明, 运动训练能够显著提高患者运动耐量, 在改善其预 后和生活质量等方面效果显著 ${ }^{[9-10]}$ 。

然而, 目前我国的心脏康复治疗仍处于起步阶 段,部分医护人员对运动训练改善心衰患者运动耐 量的生理学机制、运动训练的形式和方法缺乏认识, 心衰患者心脏康复意识淡薄、依从性较差等问题, 都是制约心脏康复广泛开展的主要因素 ${ }^{[11-12]}$ 。本研 究通过对 38 例 CHF 患者采用以运动训练为主的康 复疗法进行干预, 并与传统治疗方法进行对比, 观 察这 2 种疗法对患者心功能等级、体液因子 (血清 Ang II 、Hcy、SOD、LA 及 BNP) 的影响, 旨在系统、深 人地探究运动康复治疗对 $\mathrm{CHF}$ 患者心功能的提高 和神经内分泌系统作用机制形成的影响。

本研究结果表明,科学而规范的运动康复疗法 对于 CHF 患者效果是积极的,能够促使患者的血管 内皮功能、运动耐力、心功能出现明显的提高, 且优
于传统康复方法; 改善患者自主神经和神经内分泌 功能, 最终提高临床疗效。大量研究表明, 运动康复 治疗能给 CHF 患者带来诸多益处, 但不可忽视的是 CHF 患者属于高风险人群, 超过靶运动量会造成诸 如对机体免疫功能、消化系统、心肌的损伤, 甚至对 心肌细胞的调亡产生诱导作用 ${ }^{[8-13]}$ 。因此, 应当科学 重视运动治疗的安全性, 对进行运动训练的患者, 排除运动禁忌证并准确评估运动的风险 ${ }^{[14]}$ 。

试验所纳入的研究指标, 血清 Ang II 是一种多: 肽物质血管活性物质, 血管内皮的损伤会加速其分 泌, 可在一定程度上表明血管内皮受损程度和心衰 患者的严重程度 ${ }^{[15-16]}$; Hey 可抑制 NO 合成酶, 对 NO 合成和凝血酶调节蛋白的活性造成影响, 也可抑制 细胞内谷胱甘肽过氧化物酶的表达及活性,使血管 内皮功能受损 ${ }^{[17]}$; SOD 能够清除活性氧物质中的 $\mathrm{O}^{2-}$ 、过氧化氢等,维持正常氧化应激反应, 改善血管 内皮功能 ${ }^{[18]}$ 。以上三者均可在一定程度上反映血管 
内皮功能。LA 的含量能够体现机体组织器官氧供 求的关系,血浆中 BNP 的含量与心肌损伤部位、心 肌坏死的数量有关, 可直接体现心衰的程度 ${ }^{[19]}$ 。在 治疗结束后, 发现联合组的 Ang II 、Hey、SOD、LA、BNP 水平均优于对照组 $(P<0.05)$, 这表明运动康复疗法 对于 CHF 患者的疗效更佳。同时, 研究发现 Ang II 、Hey、SOD、LA、BNP 水平与 NYHA 心功能等级有 一定的相关性, 这或许与国内外一些报道有差异, 可能是所选病例、实验仪器、所用试剂等不同所致。

对照组的治疗结果表明,药物治疗使病情稳定 的 CHF 患者在进行合理的运动时安全可靠,这或许 在一定限度上能够降低接受运动康复治疗的患者 再人院率和病死率。对照组患者虽未接受规范的运 动康复训练, 但其各项指标均较治疗前获得一定程 度的改善 $(P<0.05)$, 这可能还与患者接受健康教育 相关。有报道表明 ${ }^{[20-21]}$, 健康教育能提高患者自我管 理能力, 使患者正确认识到运动疗法的重要性和有 效性, 增强主动参与能力, 降低心衰反复发作的风 险,一定程度上改善患者生活质量。

目前, 对于 CHF 患者的运动康复治疗还未有统 一标准方案, 仍建议根据患者病情、心肺功能和身 体状况制定针对性、科学的运动康复治疗方案。本研 究结果表明,在常规药物治疗基础上加运动康复训 练能更有效调节相关体液因子, 在一定程度上影响 CHF 患者的血管内皮功能,降低 LA 含量, 增强心功 能。但是研究所纳人的样本偏小, 研究时间及经费 有限, 关于运动康复训练对 $\mathrm{CHF}$ 患者的长期预后及 生存期影响,需进一步扩大研究加以证实。

\section{参考文献}

[1] The Writing Committee of the Report on Cardiovascular Health and Diseases in China. Report on cardiovascular health and diseases in China 2019: an updated summary [J]. Chin Cire J,2020, $35(9): 833-854$.

中国心血管健康与疾病报告编写组. 中国心血管健康与疾病 报告 2019 概要 [J]. 中国循环杂志, 2020,35(9):833-854.

[2] TEO K, LEAR S, ISLAM S, et al. Prevalence of a healthy lifestyle among individuals with cardiovascular disease in high-, middle- and low-income countries : the Prospective Urban Rural Epidemiology (PURE) study [J]. JAMA, 2016,309 (15):16131621.

[3] PONIKOWSKI P, VOORS A A, ANKER S D, et al. 2016 ESC guidelines for the diagnosis and treatment of acute and chronic heart failure. The Task Force for the diagnosis and treatment of acute and chronic heart failure of the European Society of Society (ESC), developed with the special contribution of the Heart Failure Association (HFA) of the ESC [J]. Eur J Heart Fail,
$2016,18(8): 891-975$.

[4] Committee of Exports on Rational Drug Use National Health and Family Planning Commission of The People's Republic of China; Chinese Pharmacists Association. Guidelines for rational use of drugs of heart failure (2nd edition) [J]. Chin J Front Med Sci : Electr Vers, 2019,11(7):1-78.

国家卫生计生委合理用药专家委员会, 中国药师协会.心力 衰竭合理用药指南 (第 2 版) [ J ] . 中国医学前沿杂志 (电子 版) $, 2019,11(7): 1-78$.

[5] DING R J,HU D Y, MA Y T. Chinese experts' consensus on exercise therapy for patients with coronary heart disease $[\mathrm{J}]$. Chin J Cardiol, 2015,43(7):575-588.

丁荣晶, 胡大一, 马依㓳。冠心病患者运动治疗中国专家共 识 $[J]$. 中华心血管病杂志, 2015,43(7):575-588.

[6] Chinese Society of Cardiology, Editorial Board of Chinese Journal of Cardiology. Guidelines for the diagnosis and treatment of chronic heart failure $[\mathrm{J}]$. Chin J Cardiol, 2007, 35 (12) : 10761095 .

中华医学会心血管病学分会, 中华心血管病杂志编辑委员会. 慢性心力衰竭诊断治疗指南 [J]. 中华心血管病杂志, 2007, 35(12) : 1076-1095.

[7] Annual report on cardiovascular health and diseases in China 2019 [J]. J Cardiov Pulmon Dis, 2020,39(9):145-1156.

中国心血管健康与疾病报告 $2019[\mathrm{~J}]$. 心肺血管病杂志, 2020 , 39 (9): 1145-1156.

[8] PIEPOLI M F,HOES A W, AGEWALL S, et al. 2016 European guidelines on cardiovascular disease prevention in clinical practice: The Sixth Joint Task Force of the European Society of Cardiology and Other Societies on Cardiovascular Disease Prevention in Clinical Practice (constituted by representatives of 10 societies and by invited experts) Developed with the special contribution of the European Association for Cardiovascular Prevention \& Rehabilitation (EACPR) [J]. Eur J Prev Cardiol,2016, 23 (11): NP1-NP96.

[9] FORMAN D E, SANDERSON B K, JOSEPHSON R A, et al. Heart failure as a newly approved diagnosis for cardiac rehabilitation: challenges and opportunities [J]. J Am Coll Cardiol, 2015,24 (65):2652-2659.

[10] BELARDINELLI R, GEORGIOU D, CIANCI G, et al. 10-year exercise training in chronic heart failure: a randomized controlled trial $[\mathrm{J}]$. J Am Coll Cardiol , 2012, 60(16) : 1521-1528.

[11 ] BJARNASON-WEHRENS B, MCGEE H,ZWISLER A D, et al. Cardiac rehabilitation in Europe:results from the European Cardiac Rehabilitation Inventory Survey [J]. Eur J Cardiovasc Prev Rehabil , 2010, 17(4):410-418.

[12] ZHOU F, WANG L. Research progress on the mechanism of cardiac exercise rehabilitation $[\mathrm{J}]$. Chin J Rehabil, 2016,31(3): $222-225$.

周方, 王碟. 心脏运动康复相关作用机制的研究进展 $[\mathrm{J}]$. 中 国康复, 2016,31(3):222-225.

[13] SAVAGE P A, SHAW A O, MILLER M S, et al. Effect of resistance training on physical disability in chronic heart failure $[\mathrm{J}]$. Med Sci Sports Exerc, 2011,43(8):1379-1386. 
[14] HAYKOWSKY M J, TIMMONS M P,KRUGER C, et al. Metaanalysis of aerobic interval training on exercise capacity and systolic function in patients with heart failure and reduced ejection fraction [J]. Am J Cardiol, 2013, 111 (10): 1466-1469.

[15] GAO S, WANG L C, SHANG C L. Correlation between superoxide dismutase and homocysteine levels in patients with heart failure $[\mathrm{J}]$. Chin Pract Med, 2017, 12(13):51-53

高珊, 王丽超, 尚晨䂏。心力衰竭患者超氧化物歧化酶与同型 半腅氨酸水平的相关性研究 $[\mathrm{J}]$. 中国实用医药, 2017,12(13): $51-53$.

[16] FU B W , GONG L H. Clinical Efficacy of Gelan Xinning soft capsule in treatment of coronary heart disease and its effect on serum ICAM-1 and Ang II $[\mathrm{J}]$. J Liaoning Univ Tradit Chin Med, 2020,22(1):99-102.

付博文, 宫丽鸿. 葛兰心宁软胶囊治疗冠心病临床疗效及对 血清 ICAM-1 和 Ang II 影响 [J]. 辽宁中医药大学学报, 2020, 22(1):99-102.

[17] NAGHSHTABRIZI B, SHAKERIAN F, HAJILOOI M, et al. Plasma homocysteine level and its genotypes as a risk factor for coronary artery disease in patients undergoing coronary angiography [J]. J Cardiovase Dis Res, 2012,3(4):276-279.

[18] WEI A T. Correlation analysis of serum homocysteine with mal- ondialdehyde and superoxide dismutase in patients with coronary heart disease [J]. Modern Diagn Treat, 2017,28(18):143-144. 魏爱婷. 冠心病患者血清同型半胱氨酸与丙二醛、超氧化物 歧化酶的相关性分析 [J]. 现代诊断与治疗, 2017, 28(18): 143-144.

[19] GUO G, WU X Z,SU L J. The value of BNP in the emergency department and lactic acid detection in evaluating the symptoms and prognosis of patients with acute myocardial infarction $[\mathrm{J}]$. Chin J Integr Med Cardio Cerebrovase Dis, 2017, 5(1):76-78. 郭刚, 吴先正, 苏立杰. 急诊 BNP 和乳酸检测对急性心肌梗 死病人病情及预后评估的价值 $[\mathbf{J}]$. 中西医结合心脑血管病 杂志, 2017,5(1):76-78.

[20] BETTENCOURT P, AZEVEDO A, PIMENTA J, et al. N-terminal-pro-brain natriuretic peptide predicts outcome after hospital discharge in heart failure patients $[\mathbf{J}]$. Circulation 2014, 110(5): 2168-2174.

[21] TANG Q, YIN X, ZHU L W, et al. Progress in the study of exercise rehabilitation on chronic heart failure $[\mathrm{J}]$. Rehabil Med, $2018,28(5): 65-70$.

唐强, 尹侠, 朱路文, 等. 慢性心力衰竭患者运动康复研究进 展 $[\mathrm{J}]$. 康复学报, $2018,28(5): 65-70$.

\title{
Effect of Exercise Rehabilitation Training on Humoral Factors in Patients with Chronic Heart Failure and its Effect Observation
}

\author{
DING Yi ${ }^{1}$, GUO Chenchen ${ }^{2}$, SUN Jinglong ${ }^{1}$, WANG Wanhong ${ }^{3}$, HOU Wangjun ${ }^{3}$, ZHUANG $\mathrm{He}^{3 *}$ \\ ${ }^{1}$ The Second Affiliated Hospital of Shandong University of Traditional Chinese Medicine, Jinan, Shandong 250001, China; \\ ${ }^{2}$ Neck-Shoulder and Lumbocrural Pain Hospital Affiliated to Shandong First Medical University, Jinan, Shandong 250062, China; \\ ${ }^{3}$ Shandong University of Traditional Chinese Medicine, Jinan, Shandong 250355, China
}

\begin{abstract}
Objective: To examine the effects of exercise rehabilitation training on chronic heart failure (CHF) and superoxide dismutase (SOD), homocysteine (Hcy), angiotensin II (Ang II), lactic acid (LA) and the effect of brain natriuretic peptide (BNP), providing evidence-based medical evidence for the clinical treatment of CHF. Methods: A total of 76 patients with CHF were divided into control group and combination group, with 38 patients in each group, using the random number table method. The control group received routine drug therapy; the combination group received exercise rehabilitation training in addition of the control group treatment. The effective rate and the changes of various humoral factors were observed before and after treatment. Results: The total effective rate was $89.47 \%$ in the combination group while $73.68 \%$ in the control group. The total effective rate in the combination group was better than that in the control group $(P<0.05)$. There was no significant difference in the distribution of cardiac function grades between the two groups before treatment $(P>0.05)$. The distribution of cardiac function grades in the combination group was better than that of the control group, and the difference was statistically significant $(P<0.05)$ after treatment. Both groups of patients before treatment the serum Ang- II, SOD, Hcy, LA and BNP levels comparison, there were no statistically significant differences $(P>0.05)$; After treatment in patients with serum Ang- II, Hcy, LA and BNP levels decreased significantly, the level of SOD increased obviously, the differences were statistically significant $(P<0.05)$. In the combination group after the treatment, the patient's serum of Ang- II, Hcy, LA and BNP levels decreased, compared with the control group, the differences were statistically significant $(P<0.05)$, the patient's level of SOD increased in the combination group, and was better than that of the control group, the difference was statistically significant $(P<0.05)$. Conclusion: Compared with drug therapy alone, combined exercise rehabilitation training on the basis of conventional drug therapy can regulate relevant humoral factors more effectively, affect the vascular endothelial function of CHF patients to a certain extent, reduce the content of LA, enhance cardiac function, with positive curative effect, and it is worthy of clinical application.
\end{abstract}

KEY WORDS chronic heart failure; exercise rehabilitation training; humoral factors; vascular endothelial function; cardiac function DOI : $10.3724 /$ SP.J.1329.2021.01004 